\title{
IMPLEMENTASI KEBIJAKAN PENDAFTARAN TANAH SISTEMATIS LENGKAP (PTSL) DI KABUPATEN MUARO JAMBI
}

\author{
Masnah*); Sampara Lukman; Ali Hanafiah Muhi \\ Pascasarjana Institut Pemerintahan Dalam Negeri Jakarta \\ *)email: riqbaldo_17@yahoo.co.id
}

Paper Accepted: 30 Juni 2021 Paper Reviewed: 01-07 Juli 2021 Paper Edited: 08-15 Juli 2021 Paper Approved: 18 Juli 2021

\begin{abstract}
ABSTRAK
Fokus dari penelitian ini adalah melihat Implementasi Kebijakan Pendaftaran Tanah Sistematis Lengkap (PTSL) di Kabupaten Muaro Jambi, faktor yang menghambat Implementasi Kebijakan Pendaftaran Tanah Sistematis Lengkap (PTSL) di Kabupaten Muaro Jambi serta upaya yang sebaiknya dilakukan untuk keberhasilan Implementasi Kebijakan Pendaftaran Tanah Sistematis Lengkap (PTSL) di Kabupaten Muaro Jambi. Penelitian menggunakan teori oleh Van Meter dan Van Horn terkait implementasi kebijakan publik dan faktor yang menghambat serta melakukan analisis SWOT dan litmus test untuk menentukan upaya yang sebaiknya dilakukan untuk keberhasilan Implementasi Kebijakan. Penelitian ini menggunakan metode kualitatif dengan pendekatan deskriptif. Dalam mengumpulkan data, peneliti melakukan observasi, wawancara dan mengumpulkan dokumen tentang Implementasi Kebijakan Pendaftaran Tanah Sistematis Lengkap (PTSL) di Kabupaten Muaro Jambi. Hasil penelitian menunjukkan bahwa Implementasi Kebijakan Pendaftaran Tanah Sistematis Lengkap (PTSL) di Kabupaten Muaro Jambi belum optimal. Meskipun dilihat dari karakteristik organisasi pelaksana, Komunikasi Antar Organisasi dan Pelaksanaan Kegiatan, sikap pelaksana sudah cukup baik. Kemudian aspek lingkungan sosial dan kultur yang cukup memahami maksud dan tujuan dari Implementasi Kebijakan Pendaftaran Tanah Sistematis Lengkap (PTSL), serta faktor politik yang sudah cukup baik dengan adanya dukungan dari kepala daerah. Strategi yang sebaiknya dilakukan untuk keberhasilan Implementasi Kebijakan Pendaftaran Tanah Sistematis Lengkap (PTSL) di Kabupaten Muaro Jambi adalah: 1. Mengoptimalkan fungsi Bagian Pertanahan dan Batas Wilayah dalam menyelesaikan Masalah Pertanahan dan Batas Wilayah; 2. Meningkatkan komitmen pemerintah daerah dalam Implementasi Kebijakan Pendaftaran Tanah Sistematis Lengkap (PTSL); 3. Melaksanakan sosialisasi Implementasi Kebijakan Pendaftaran Tanah Sistematis Lengkap (PTSL) secara menyeluruh.
\end{abstract}

Kata Kunci: Implementasi Kebijakan, Faktor Penghambat, PTSL

\section{PENDAHULUAN}

Tanah mempunyai arti penting dalam kehidupan manusia; sebagai negara agraris Tanah merupakan faktor penting bagi bangsa Indonesia baik sebagai daya produksi maupun sebagai pemukiman. Oleh sebab itu, pengelolaan tanah dalam arti pengaturan penguasaan tanah, penatagunaan tanah, pengurusan hak-hak tanah, serta pengukuran dan pendaftaran tanah perlu ditata dan diatur sedemikian rupa sehingga tanah dapat digunakan sebesar-besarnya untuk kemakmuran rakyat seperti yang diamanatkan oleh Undang-undang Dasar 1945 Pasal 33 ayat (3). 


\begin{abstract}
Seiring dengan meningkatnya pertumbuhan penduduk Indonesia dan percepatan pembangunan dewasa ini membawa kepada suatu situasi dimana kebutuhan akan tanah semakin meningkat, demikian juga dengan permohonan jasa pelayanan di bidang pertanahan cenderung terus meningkat. Lahirnya konflik -konflik pertanahan pada dasarnya bermuara pada lemahnya sertifikasi kepemilikan akan tanah serta kurangnya kesadaran masyarakat dalam memenuhi kewajiban administratifnya seperti melakukan pendaftaran hak atas tanah mereka guna adanya kepastian hukum.
\end{abstract}

Hukum kepemilikan tanah di indonesia di atur dalam Undang-Undang No 5 Tahun 1960 tentang perturan dasar Pokok-Pokok Agraria yang didalamnya terdapat suatu konsepsi hukum tanah nasional dimana semua tanah di seluruh wilayah indonesia adalah milik bangsa indonesia yang sekaligus menjadi simbol kesatuan bagi keutuhan bangsa Indonesia. Dalam landasn ini dikemukakan bahwa tanah di Indonesia tidak dapat diperjualbelikan atau diperdagangkan dan tidak diperkenankan menjadi objek penguasaan yang bisa menimbulkan disintegrasi bangsa. Namunn bukan berarti pemerintah tidak memberikan hak-hak atas tanah tersebut kepada masyarakat seperti yang diatur dalam Pasal 16 UUPA seperti hak guna- bangunan, hak pakai, hak sewa serta hak milik dan beberapa hak lainnya.

Jaminan kepastian hukum yang hendak diwujudkan dalam pendaftaran tanah ini, meliputi kepastian status hak yang didaftar, kepastian subjek hak, dan kepastian objek hak. Pendaftaran hak ini menghasilkan sertifikat sebagai tanda bukti haknya. Inti dari muatan ketentuan tersebut menentukan bahwa "bukti sah kepemilikan hak atas tanah adalah sertifikat"

Dengan demikian persoalan-persoalan yang berhubungan dengan tanah seperti penguasaan tanah, pemilikan dan penggunaan tanah oleh orang atau badan hukum yang melanggar ketentuan-ketentuan peraturan perundang-undangan Pertanahan yang berlaku, jual beli tanah di luar prosedur yang berlaku, penggunaan tanah yang tidak sesuai dengan peruntukannya, adanya sertifikat palsu, sertifikat tumpang tindih, manipulasi tanah dan sebagainya dapat diminimalisir.

Secara nasional, kementrian agraria dan tata ruang (ART)/BPN mengusulkan 5 juta bidang tanah yang akan di data selanjutnya dibuatkan sertipikat gratis oleh masing-masing BPN setempat di daerah. Pada dasarnya penerbitan sertipikat tanah melalui program PTSL ini tidak jauh berbeda dengan penerbitan sertipikat tanah melalui program nasional agraria (PRONA) yaitu sama-sama dilaksanakan secara gratis, juga dengan prasyarat dari pendaftaran hak hingga penerbitan atau pelayanan dari BPN, pra pelayanan dibebankan oleh pemilik tanah, seperti BPHTB, alas hak, materai, patok batas ditanggung oleh pemilik lahan. Yang membedakan PTSL dengan PRONA adalah melalui program prona, pendataan prona sebagai pnerima sertipikat prona dilakukan secara merata diseluruh desa dan kelurahan dalam satu kabupaten. Sementara program PTSL pendataannya dilakukan terpusat di satu desa sadan berbeda dengan prona yang hany menerbitkan sertipikat tidak menyeluruh pada semua bidang tanah yang tidak bersertipikat dalam satu daerah sementara PTSL seluruh tanah dalam daerah tersebut yang belum memiliki sertipikat akan dibuatkan.

Kendala yang dihadapi dalam prona adalah Kepala Desa yang tidak mau mengikuti program tersebut. Dalam pelaksanaannya tidak semua hal dibiayai APBN. Salah satunya patok. Untuk penentuan batas tanah diperlukan paling sedikit empat patok.

Sebagai Negara hukum, Indonesia dalam banyak kasus memperlihatkan bahwa kekerasan ini timbul dari kepemilikan permasalahan sertipikat tanah. Hal ini yang sering didengungkan akhir-akhir ini. Seperti data yang ditunjukkan oleh Konsirium Pembaruan Agraria (KPA), di tahun 2017 tercatat sedikitnya terjadi 659 konflik agrarian atau pertanahan di berbagai wilayah di dengan luasan 520.491,87 hektar. Konflik- konflik ini melibatkan sedikitnya 652.738 keluarga. Dibanding 2016, konflik tahun ini menunjukkan kenaikan siginifikan alias $50 \%$.

Dari semua sektor, perkebunan menempati posisi pertama. Sebanyak 208 konflik agraria sektor ini sepanjang 2017, atau 32\% dari seluruh kejadian. Properti menempati posisi kedua dengan 199 atau 30\% konflik. Ketiga infrastruktur dengan 94 (14\%), disusul sektor pertanian 78 (12\%). Sektor kehutanan ada 30 (5\%), sektor pesisir dan kelautan 28 (4\%), terakhir pertambangan $22 \quad(3 \%)$. Untuk infrastruktur, konflik terjadi pada 52.607,9 hektar dan pertambangan 45.792,8 hektar. Sektor pesisir dan kelautan 41.109,47 hektar, sektor pertanian pangan 38.986,24 hektar. Luasan konflik sektor properti 10.337,72 hektar. Sedangkan, selama tiga tahun pemerintahan Jokowi-Jusuf Kalla (2015-2017), terjadi 1.361 konflik agraria. 
Pada Undang - Undang Pokok Agraria di atur bahwa hak - hak untuk tanah yang dapat di daftarkan adalah Hak Milik, Hak Guna Usaha, Hak Guna Bangunan, Hak Pakai dan Hak Sewa untuk bangunan yang tidak wajib untuk di daftarkan. Pada perkembangannya amanat dari pasal 19 Undang - Undang Pokok Agraria pada pelaksanaannya, di bentuklah Peraturan Pemerintah Nomor 24 Tahun 1997 dari perubahan peraturan Pemerintah Nomor 10 Tahun 1961 tentang pendaftaran tanah, yang di dalamnya di atur tentang objek pendaftaran tanah yaitu berupa Hak Milik, Hak Guna Usaha, Hak Guna Bangunan, Hak Pakai, Tanah Hak Pengelolaan, Tanah Wakaf, Hak Milik Atas Satuan Rumah Susun, Hak Tanggungan Dan Tanah Negara.

Perubahan peraturan pemerintah ini di anggap mempunyai kedudukan yang sangat strategis dan menentukan, bukan hanya sebagai pelaksana akan tetapi di harapkan juga sebagai tulang punggung yang menjadi berjalannya administrasi pertanahan sebagai salah satu program tertib pertanahan dan Hukum pertanahan di Indonesia. Masalah - masalah yang selama ini ada di masyarakat wajib untuk di selesaikan di carikan solusinya. Melatarbelakangi hal - hal tersebut, guna untuk memperbaiki dan meningkatkan layanan kepada masyarakat pada bidang pertanahan, maka Badan Pertanahan Nasional Republik Indonesia membuat terobosan - terobosan baru untuk memecahkan masalah yang ada di masyarakat untuk melaksanakan pendaftaran tanah atas seluruh bidang tanah di Indonesia.

Dengan banyaknya masalah di bidang pertanahan, salah satunya adalah kebijakan Pendaftaran Tanah Sistematis Lengkap (PTSL). Kebijakan yang awalnya dikenal dengan program nasional (prona) ini merupakan hal yang penting dan strategis untuk dokumen daerah yang memiliki kepastian hukum dalam mewujudkan kebenaran atas subyek dan objek tanah itu sendiri. Pendekatan yang dilakukan dalam PTSL ini adalah melalui desa per desa, kabupaten per kabupaten, serta kota per kota di seluruh Indonesia.

Pendaftaran tanah adalah suatu rangkaian kegiatan, yang dilakukan oleh negara/pemerintah secara terus menerus dan teratur, berupa pengumpulan keterangan atau data tertentu mengenai tanah-tanah tertentu yang ada di wilayah-wilayah tertentu, pengolahan, penyimpanan dan penyajiannya bagi kepentingan rakyat, dalam rangka memberikan jaminan kepastian hukum di bidang pertanahan, termasuk penerbitan tanda-buktinya dan pemeliharaannya.
Peraturan Menteri Agraria/Kepala Badan Pertanahan Nasional Nomor 3 tahun 1997 tentang ketentuan pelaksanaan Pemerintah Nomor 24 Tahun 1997 tentang Pendaftaran Tanah sebagaimana telah di ubah dengan peraturan Kepala Badan Pertanahan Nasional Nomor 8 Tahun 2012 tentang perubahan atas peraturan Menteri Agraria /Kepala Badan Pertanahan Nasional Nomor 3 Tahun 1997 tentang ketentuan pelaksanaan Peraturan Pemerintah Nomor 24 Tahun 1997 Tentang Pendaftaran Tanah. Dimana pergantian Perundang - undangan tentang pendaftaran hak atas tanah tersebut tertuang dalam peraturan Menteri Agraria dan Tata Ruang/Kepala Badan Pertanahan Nasional Nomor 6 Tahun 2018 tentang Pendaftaran Tanah Sistematis Lengkap (PTSL).

Pendaftaran Tanah Sistematis Lengkap (PTSL) adalah kegiatan pendaftaran tanah untuk pertama kali yang dilakukan secara serentak bagi semua objek pendaftaran tanah di seluruh wilayah Republik Indonesia dalam satu wilayah desa/kelurahan atau nama lainnya yang setingkat itu, yang meliputi pengumpulan dan penetapan kebenaran data fisik dan data yuridis mengenai satu atau beberapa objek pendaftaran tanah untuk keperluan pendaftarannya.

Pendaftaran Tanah Sistematik Lengkap (PTSL) adalah kegiatan pendaftaran tanah untuk pertama kali yang dilakukan secara serentak yang meliputi semua objek pendaftaran tanah yang belum didaftar dalam satu wilayah desa/kelurahan atau nama lainnya yang setingkat dengan itu dalam rangka memberikan jaminan kepastian hukum dan perlindungan hukum hak atas tanah rakyat secara adil dan merata, serta mendorong pertumbuhan ekonomi negara pada umumnya dan ekonomi rakyat khususnya, perlu dilakukan percepatan pendaftaran tanah lengkap di seluruh wilayah Republik Indonesia.

Kabupaten Muaro Jambi merupakan salah satu Kabupaten di Provinsi Jambi yang berasal dari pemekaran Kabupaten Batanghari. Wilayah Kabupaten Muaro Jambi menempati posisi cukup strategis sebagai dukungan bagi pengembangan wilayah secara lebih cepat. Wilayah Kabupaten Muaro Jambi mempunyai aksesibilitas yang tinggi terhadap pasar regional,.

Dari luas wilayah Kabupaten Muaro Jambi seluas $\pm 5.246 \mathrm{Km}^{2}$ / $524.600 \mathrm{Ha}$ yang merupakan kawasan Budidaya Pertanian dan Non Pertanian seluas $360.000 \mathrm{Ha}(69 \%)$ yang terdiri dari Pemukiman, Industri, Jalan, Perkebunan, Sawah. Kemudian yang merupakan 
kawasan Hutan dan Lindung seluas $164.594 \mathrm{Ha}$ (31 \%). Dari luasan kawasan Budidaya Pertanian dan Non Pertanian yang merupakan 69\% dari luas wilayah Kabupaten Muaro Jambi masih terdapat seluas \pm 134.238 Ha yang belum memiliki sertipikat hak milik. Ini berarti masih sekitar 37,29\% dari wilayah kawasan Budidaya Pertanian dan Non Pertanian belum memiliki legalitas hak milik atau sekitar $\pm 25,59 \%$ dari luas wilayah Kabupaten Muaro Jambi yang belum bersrtipikat. Luasan Kabupaten Muaro Jambi jika berdasarkan darat, kawasan hutan, dan Hak Guna Usaha (HGU) yang terdaftar adalah :Darat $517.639 \mathrm{Ha}$, Kawasan Hutan=164.594Ha,Tanah Terdaftar Skala Besar $(\mathrm{HGU})=60.000 \mathrm{Ha}$

Kantor Pertanahan Kabupaten Muaro Jambi dalam menyelenggarakan tugas dan fungsinya didukung oleh Sumber Daya Aparatur sebanyak 35 orang, terdiri dari 21 pejabat struktural dan 14 jabatan fungsional umum (JFU), dan dari jumlah JFU tersebut sebagai petugas ukur sebanyak 6 orang. Proporsi kompetensi ideal untuk petugas ukur diharapkan $40 \%$ dari jumlah pegawai. Saat ini jumlah sumber daya aparatur petugas ukur masih kurang, yaitu baru mencapai sekitar 6 orang dari jumlah pegawai keseluruhan sebanyak 35 orang atau hanya $17,14 \%$.

Volume pelayanan pertanahan di wilayah Kabupaten Muaro Jambi cukup tinggi, sehingga untuk menunjang kelancaran dalam pelayanan kepada masyarakat perlu didukung sarana dan prasarana yang memadai, seperti halnya adanya gedung arsip dan alat ukur yang memadai yang merupakan sarana yang sangat penting untuk menunjang kelancaran pelaksanaan tugas. Pada Kantor Pertanahan Kabupaten Muaro Jambi memiliki 6 (enam) Kepala Seksi. Namun dari 6 Kepala Seksi ini hanya ada 2 Kepala Seksi yang memiliki gedung arsip dan 4 Kepala Seksi Lainnya belum memiliki gedung arsip.

Pada tahun 2017 secara Nasional, Kementerian Agraria dan Tata Ruang (ATR)/Badan Pertanahan Nasional mengusulkan 5 juta bidang tanah yang akan didata selanjutnya dibuatkan sertipikat gratis oleh masing - masing BPN setempat di daerah daerah. Dari hasil penelitian penulis di BPN Kabupaten Muaro Jambi menurut Bapak Suharna selaku Kepala Kantor Pertanahan Kabupaten Muaro Jambi mengatakan, untuk Wilayah Kabupaten Muaro Jambi sendiri selaku mendapatkan peningkatan target bidang sertipikasi mulai dari tahun 2017 sampai dengan tahun 2020 ini.

Dilihat bahwa penetapan target Pelaksanaan Kebijakan Pendaftaran Tanah
Sistematis Lengkap (PTSL) di Kabupaten Muaro Jambi mulai dari tahun 2017 sampai dengan tahun 2020 secara menyeluruh mengalami peningkatan peningkatan yang signifikan. Namun apabila dilihat secara per tahun, pada tahun 2017 mendapatakan 2 tahap target PTSL tahap pertama mendapatkan target 4.200 bidang dan tahap keduanya mendapatkan target 8.000 bidang. Pada tahun 2018 mengalami penambahan target yaitu menjadi 17.000 bidang namun pada tahun 2019 mengalami pengurangan target menjadi 14.000 bidang. Penurunan target ini menurut penjelasan yang diterima dari Kepala Kantor Pertanahan Kabupaten Muaro Jambi disebabkan oleh capaian pada tahun 2018 yang hanya mencapai 7.163 bidang dari 17.000 bidang yang di targetkan.

Berdasarkan latar belakang yang telah diuraikan di atas dan memandang Kebijakan Pendaftaran Tanah Sistematis Lengkap (PTSL) merupakan program yang sangat bermanfaat dalam mengurangi masalah di bidang pertanahan serta salah satu upaya sinergitas program di Kabupaten Muaro Jambi dengan Program Strategis Nasional yaitu Kebijakan Satu Peta (One Map Policy), maka peneliti merasa penting untuk mengangkat judul "IMPLEMENTASI KEBIJAKAN PENDAFTARAN TANAH SISTEMATIS LENGKAP (PTSL) DI KABUPATEN MUARO JAMBI."

\section{Identifikasi Masalah}

Berdasarkan dari latar belakang tersebut dapat diidentifikasikan masalah-masalah sebagai berikut :

1. Masih banyak bidang tanah yang belum memiliki sertipkat hak milik di Kabupaten Muaro Jambi.

2. Terbatasnya sumber daya aparatur pada Kantor Pertanahan Kabupaten Muaro Jambi dalam mendukung Kebijakan Pendaftaran Tanah Sistematis Lengkap (PTSL).

3. Terbatasnya anggaran yang dialokasikan Pemerintah Pusat pada Kantor Pertanahan Kabupaten Muaro Jambi.

4. Besarnya pembiayaan yang dilkeluarkan perorangan dalam pembuatan sertipikat hak milik di Kabupaten Muaro Jambi.

5. Kurangnya pemahaman masyarakat Kabupaten Muaro Jambi terhadap Kebijakan Pendaftaran Tanah Sistematis Lengkap (PTSL). 


\section{Pembatasan Masalah}

Pembatasan suatu masalah digunakan untuk menghindari adanya penyimpangan maupun pelebaran pokok masalah agar penelitian ini lebih terarah dan memudahkan dalam pembahasan sehingga tujuan penelitian akan tercapai. Beberapa pembatasan masalah dalam penelitian ini adalah sebagai berikut:

1. Ruang lingkup masalah hanya meliputi seputar Pendaftaran Tanah Sistematis Lengkap (PTSL) di Kabupaten Muaro Jambi.

2. Informasi yang disajikan yaitu implementasi Pendaftaran Tanah Sistematis Lengkap (PTSL) di Kabupaten Muaro Jambi, faktorfaktor yang menghambat serta stragegi yang perlu dilakukan dalam implementasi Pendaftaran Tanah Sistematis Lengkap (PTSL) di Kabupaten Muaro Jambi.

\section{Perumusan Masalah}

Berdasarkan uraian tersebut, maka dapat dirumuskan permasalahan yang akan menjadi fokus dalam penelitian ini sebagai berikut :

1. Bagaimana Implementasi Kebijakan Pendaftaran Tanah Sistematis Lengkap (PTSL) di Kabupaten Muaro Jambi?

2. Apa saja faktor yang menghambat Implementasi Kebijakan Pendaftaran Tanah Sistematis Lengkap (PTSL) di Kabupaten Muaro Jambi ?

3. Apa strategi yang sebaiknya dilakukan untuk keberhasilan Implementasi Kebijakan Pendaftaran Tanah Sistematis Lengkap (PTSL) di Kabupaten Muaro Jambi?

\section{Tinjauan Pustaka}

\section{Teori Pemerintahan}

Pemerintah atau Government dalam bahasa indonesia berarati pengarahan dan administrasi yang berwenang atas kegiatan orang-orang dalam sebuah negara, negara bagian, atau kota dan sebagainya. Bisa juga berarti lembaga atau badan yang menyelenggarakan pemerintahan negara, negara bagian, atau kota, dan sebagainya.

Menurut W.S Sayre (1960:26) pemerintah dalam definisi terbaiknya adalah sebagai organisasi dari negara yang memperlihatkan dan menjalankan kekuasaannya. Selanjutnya menurut David Apter (1977:32), pemerintah adalah satuan anggota yang paling umum yang memiliki tanggung jawab tertentu untuk mempertahankan sistem yang mecangkupnya dan monopoli praktis yang menyangkut kekuasaan paksaannya (Inu Kencana S. 2010:11)

Selanjutnya, Daerah adalah lingkungan pemerintah : wilayah, daerah diartikan sebagai bagian permukaan bumi; lingkungan kerja pemerintah, wilayah; selingkup tempat yang dipakai untuk tujuan khusus, wilayah; tempattempat sekeliling atau yang dimaksud dalam lingkungan suatu kota; tempat yang terkena peristiwa sama; bagian permukaan tubuh.

\section{Fungsi Pemerintah}

Menurut Adam Smith (1976:18), pemerintah suatu negara mempunyai tiga fungsi pokok yaitu memelihara keamanan dan pertahanan dalam negeri, menyelenggarakan peradilanm dan enyediakan barang-barang yang tidak disediakan oleh pihak swasta. Kaitan dari permasalahan fungsi atau tujuan diatas hampir selalu dijumpai padasetiap permasalahan mengenai tujuan atau kebijakan tertentu, misalnya mengenai tujuan untuk politik pembangunan, tujuan untuk kebijakan perdagangan, kesempatan kerja, kesempatan memperoleh pendidikan pertanian, perburuhan, pengangkutan, dan lain-lain.Peranan pemerintah dalam perekonomian antara lain:

a. Menetapkan kerangka hukum (legal framework) yang melandasi suatu perekonomian,

b. Mengatur atau meregulasi perekonomian dengan alat subsidi dan pajak,

c. Memproduksi komoditas tertentu dan menyediakan berbagai fasilitas seperti kredit, penjaminan simpanan, dan asuransi,

d. Membeli komoditas tertentu termasuk yang dihasilkan oleh perusahaan swasta, misalnya persenjataan.

e. Meredistribusikan (membagi ulang) pendapatan dari satu kelompok ke kelompok lainnya, dan

f. Menyelenggarakan sistem jaminan sosial, misalnya memelihara anak-anak terlantar, menyantuni fakir miskin, dan sebagainya.

\section{Kebijakan Publik dan Implementasi}

Kebijakan itu adalah suatu tindakan yang mengarah pada tujuan yang diusulkan oleh seseorang, kelompok, atau pemerintah dalam lingkungan tertentu sehubungan dengan adanya hambatan - hambatan tertentu seraya mencari peluang untuk mencapai tujuan atau mewujudkan sasaran yang diinginkan. Rose 
dalam Muchlis Hamdi (2014:36) mengartikan kebijakan lebih sebagai suatu rangkaian panjang dari kegiatan-kegiatan yang berkaitan dan akibatnya bagi mereka yang berkepentingan, dari pada hanya sekedar suatu keputusan.. .

Adapun model menurut Donald S. Van Meter dan Carl E. Van Horn dalam Wahab (2012:135) ada enam variabel yang mempengaruhi keberhasilan implementasi kebijakan, yaitu :

1) Standar dan sasaran kebijakan Standar dan sasaran kebijakan harus jelas dan terukur,sehingga tidak menimbulkan interpretasi yang dapat menyebabkan terjadinya konflik di antara para agen implementasi.

2) Sumber daya

Implementasi Kebijakan perlu didukung oleh sumber daya, baik itu sumber daya manusia (human resources) maupun sumber daya non manusia(non-human resources).

3) Komunikasi antar organisasi dan penguatan aktivitas

Dalam berbagai kasus, implementasi sebuah program terkadang perlu di dukung dan dikoordinasikan dengan instansi lain agar tercapai keberhasilan yang diinginkan.

4) Karakteristik agen pelaksana

Sejauh mana kelompok - kelompok kepentingan memberikan dukungan bagi implementasi kebijakan. Termasuk di dalamnya karakteristik para partisipan yakni mendukung atau menolak, kemudian juga bagaimana sifat opini publik yang ada dilingkungan dan apakah elite politik mendukung implementasi kebijakan.

5) Kondisi sosial, ekonomi dan politik Kondisi sosial, ekonomi dan politik mencakup sumber daya ekonomi lingkungan yang dapat mendukung keberhasilan implementasi kebijkan.

6) Disposisi implementator

Disposisi implementor mencakup tiga hal penting, yaitu :

a. Respons implementator terhadap kebijakan, yang akan mempengaruhi kemauannya untuk melaksanakan kebijakan

b. Kognisi, yakni pemahamannya terhadap kebijakan

c. Intensitas disposisi implementator yakni prefensi nilai yang dimiliki oleh implementator.
Dari pengertian menurut para ahli diatas maka penulis menarik kesimpulan bahwa, implementasi kebijakan ialah suatu aktivitas yang dilaksanakan setelah di keluarkan pengarahan yang sah dari suatu kebijakan yang meliputi upaya input untuk menghasilkan output atau outcome bagi masyarakat. Maka penulis menyimpulkan bahwa kebijakan publik adalah suatu tindakan yang sengaja dibuat kemudian dilaksankan ataupun tidak oleh pemerintah untuk tercapainya tujuan kebijakan tersebut.

\section{METODE PENELITIAN}

Penelitian menurut L.R Gray dalam Sumanto (2014:4) adalah "penggunaan metode ilmiah secara formal dan sistematis untuk menjawab dan menyelesaikan masalah". Menurut Nazir (2014:70) dijelaskan bahwa "penelitian adalah proses mencari sesuatu secara sistematik dalam waktu yang dengan menggunakan metode ilmiah serta aturan-aturan yang berlaku". Kemudian menurut Hussey dalam Silalahi (2010:2) mengatakan bahwa "penelitian sebagai suatu proses penyelidikan, sistematis dan metodis, sebagai solusi atas suatu masalah dan meningkatkan pengetahuan".

Suatu penelitian ilmiah harus memenuhi 4 (empat) kriteria menurut Gulo (2010:17) adalah sebagai berikut:

1. Penelitian dilakukan secara sistematis. Prosesnya dilakukan dari satu tahap ke tahap berikutnya. Setiap tahap harus dilakukan secara berurut, tidak boleh melangkahi tahap sebelumnya untuk langsung pada tahap terakhir atau tahap yang jauh di atasnya.

2. Penelitian dilakukan secara terkendali. Perumusan konsep dan hipotesis secara operasional merupakan kendali dalam mengarahkan seluruh kegiatan penelitian.

3. Penelitian dilakukan secara empiris. Masalah-masalah yang akan diteliti adalah masalah yang bersifat empiris. Semua konsep yang tercakup dalam penelitian harus terhubung secara operasional dalam dunia nyata.

4. Penelitian bersifat kritis. Kritis disini berarti ada tolak ukur yang dipakai untuk menentukan sesuatu yang dapat diterima, baik secara eksplisit maupun implisit.

Dalam penelitian ini penulis perlu melakukan proses penjajakan atau penggalian suatu permasalahan secara mendalam dan 
komprehensif dari kumpulan informasi yang pada akhirnya bertujuan untuk menggambarkan permasalahan. Berdasarkan hal yang peru dilakukan penulis dalam penelitian dan penjelasan para ahli di atas maka dapat disimpulkan bahwa metode dalam penelitian ini menggunakan metode kualitatif dengan pendekatan deskriptif

\section{Teknik Pengumpulan Data}

Data merupakan hal yang sangat diperlukan dalam sebuah penelitian sebagai bahan analisis dan juga bahan untuk memperkuat penelitian sehingga peneltian dapat dipertanggungjawabkan. Memperoleh sumber data dapat dibedakan menjadi 2 (dua) menurut Sugiyono (2010:137), yaitu:

1. Data primer

Sumber data primer adalah sumber yang langsung memberikan data kepada pengumpul data. Data primer dalam penelitian ini diperoleh dari hasil wawancara dengan informan.

2. Data sekunder

Sumber data sekunder yaitu sumber data yang memberikan data secara tidak langsung kepada pengumpul data. Hal ini karena data sebelumnya telah diolah dan disajikan oleh orang lain.

Data sekunder dalam penelitian ini diperoleh dari penelaahan bahan-bahan bacaan dan literatur lainnya yang berkaitan dengan fokus penelitian berupa buku-buku, peraturan, laporan, serta dokumen yang berkaitan dengan Implementasi Program Pendaftaran Tanah Sistematis Lengkap (PTSL).

\section{PEMBAHASAN}

\section{Implementasi Kebijakan Pendaftaran Tanah Sistematis Lengkap (PTSL) di Kabupaten Muaro Jambi \\ Dalam memperoleh data-data} Implementasi Kebijakan Pendaftaran Tanah Sistematis Lengkap (PTSL) di Kabupaten Muaro Jambi, peneliti menggunakan model pendekatan implementasi kebijakan yang dirumuskan oleh Van Meter dan Van Horn sebagai berikut:

\section{Standar dan Sasaran Kebijakan}

Pelaksanaan tugas pokok dan fungsi, Kantor Pertanahan Kabupaten Muaro Jambi memiliki standar dan sasaran yang harus dicapai dalam kegiatannya terutama pelayanan kepada masyarakat dan memperoleh kepercayaan dari masyarakat.
Berdasarkan wawancara dengan Kepala Kantor Wilayah Badan Pertanahan Provinsi Jambi pada tanggal 06 Maret 2020 di Ruang Kerja Kepala Kantor Wilayah Badan Pertanahan Provinsi Jambi, beliau mengatakan bahwa:

"untuk Implementasi Kebijakan
Pendaftaran Tanah Sistematis Lengkap di
Kabupaten Muaro Jambi, beliau
memerintahkan Kepalar Kantor
Pertanahan Kabupaten Muaror Jambi
untuk melakukan upaya pencapaian target
yang optimal".

Setiap kebijakan diperlukan suatu dasar yang menaungi kebijakan program tersebut. Untuk Implementasi Kebijakan Pendaftaran Tanah Sistematis Lengkap di Kabupaten Muaro Jambi berdasarkan pada kebijakan yaitu melalui Peraturan Menteri Agraria dan Tata Ruang/Kepala Kantor Pertanahan Kabupaten Muaro Jambi Republik Indonesia Nomor 6 Tahun 2018 tentang Pendaftaran Tanah Sistematis Lengkap, kemudian Keputusan Bersama Menteri Menteri Agraria dan Tata Ruang/Kepala Kantor Pertanahan Kabupaten Muaro Jambi Republik Indonesia, Menteri dalam Negeri Republik Indonesia, Menteri Desa, Pembangunan Daerah Tertinggal dan Transmigrasi Nomor:25/SKB/V/2017, Nomor:590-3167A Tahun 2017 dan Nomor:34 Tahun 2017 tentang Pembiayan Persiapan Pendaftaran Tanah Sistematis. Selanjutnya diturunkan Peraturan Bupati Nomor 7 Tahun 2019 tentang Pembiayaan Persiapan Pendaftaran Tanah Sistematis Lengkap yang dibebankan kepada Masyarakat di Kabupaten Muaro Jambi.

Tujuan dalam Peraturan Bupati Nomor 7 Tahun 2019 tentang Pembiayaan Persiapan Pendaftaran Tanah Sistematis Lengkap yang dibebankan kepada Masyarakat di Kabupaten Muaro Jambi pada pasal 3 adalah untuk melakukan penyeragamaan biaya yang dibebankan kepada masyarakat guna persiapan Pendaftaran Tanah Sistematis Lengkap, sehingga dapat mengahapus adanya pungutanpungutan liar yang tidak mempunyai dasar hukum yang membebani masyarakat.

Dengan adanya kebijakan tersebut maka Kantor Pertanahan Kabupaten Muaro Jambi mengimplementasikan Kebijakan Pendaftaran Tanah Sistematis Lengkap di Kabupaten Muaro Jambi dengan baik sehingga mencapai tujuan dapat mengoptimalkan upaya pencapaian target PTSL. adanya kebijakan tersebut maka Kantor Pertanahan Kabupaten Muaro Jambi mengimplementasikan Berdasarkan data Kantor Pertahanan Muaro Jambi mulai dari tahun 
2017 sampai dengan tahun 2020 secara menyeluruh mengalami peningkatan peningkatan yang signifikan. Namun apabila dilihat secara per tahun, pada tahun 2017 mendapatakan 2 tahap target PTSL tahap pertama mendapatkan target 4.200 bidang dan tahap keduanya mendapatkan target 8.000 bidang. Pada tahun 2018 mengalami penambahan target yaitu menjadi 17.000 bidang namun pada tahun 2019 mengalami pengurangan target menjadi 14.000 bidang. Penurunan target ini menurut penjelasan yang diterima dari Kepala Kantor Pertanahan Kabupaten Muaro Jambi disebabkan oleh capaian pada tahun 2018 yang hanya mencapai 7.163 bidang dari 17.000 bidang yang di targetkan. Pada tahun 2020 Kabupaten Muaro Jambi awal mendapatkan target 20.000 bidang namun dikarenakan wabah pandemic covid 19 target di Kabupaten Muaro Jambi diturunkan menjadi 5.600 bidang dan semuanya terselesaikan dengan capaian targetnya $100 \%$.

\section{Sumber Daya}

\section{a. Sumber Daya Manusia}

Mengenai sumber daya manusia dan sumber daya lainnya saling berkaitan satu sama lainnya dalam rangka aktivitas kerja organisasi, karena pada hakikatnya manusia itu sendiri adalah mengantar organisasi untuk mencapai tujuannya. Sumber daya manusia merupakan kunci dari organisasi karena sistem dan mekanisme dalam organisasi akan bermuara pada sumber daya manusia.

Kondisi sumber daya manusia di Kantor Pertanahan Kabupaten Muaro Jambi dari jumlah pegawai dan latar belakang pendidikan belum cukup baik, yaitu jumlah S2 sebanyak 2 orang, S1 sebanyak 16 orang dan D1 sebanyak 21 orang dan SMA sebanyak 2

Sumber daya manusia yang menangani implementasikan Kebijakan Pendaftaran Tanah Sistematis Lengkap di Kabupaten Muaro Jambi yaitu seluruh pegawai Kantor Pertanahan Kabupaten Muaro Jambi. Mengikuti perkembangan regualsi peraturan tentang Pendaftaran Tanah Sistematis Lengkap yang terus diperbarui dibutuhkan kemampuan pegawai yang kompeten untuk memahami bekerja sesuai dengan peraturan perundangundangan yang berlaku. Berdasarkan wawancara dengan Kepala Kantor Pertanahan Kabupaten Muaro Jambi Bapak Suharna, SH pada tanggal 09 Maret 2020 di Ruang Kerja Kepala Kantor Pertanahan Kabupaten Muaro Jambi, menyatakan bahwa:

\begin{abstract}
"Sumber daya manusia yang ada belum semuanya berkompeten. Untuk meningkatkan kompetensi dan pengetahuan biasanya ada pelatihan di Kementerian ATR/BPN RI atau Badan Informasi Geospasial (BIG) karena untuk Implementasi Pendaftaran Tanah Sistematis Lengkap diperlukan petugas ukur dengan jumlah yang dapat disesuaikan dengan target, sedangkan di Kantor Pertanahan Kabupaten Muaro Jambi hanya 6 orang petugas ukur dengan kapasitas Sumber Daya Aparatur yang berbeda-beda."
\end{abstract}

Berdasarkan penjelasan di atas, maka dapat diketahui bahwa untuk sumber daya manusia yang memiliki kompetensi dan keahlian dalam Implementasi Pendaftaran Tanah Sistematis Lengkap masih kurang, perlu dilakukannya penambahan aparatur atau penambahan aparatur melalui pola penerimaan pegawai pemerintah dengan perjanjian kerja.

\section{b. Sarana dan Prasarana/ Fasilitas Penunjang}

Sarana dan prasarana/ fasilitas penunjang Implementasi Pendaftaran Tanah Sistematis Lengkap dalam mencapai target yang opitimal di Kantor Pertanahan Kabupaten Muaro Jambi dapat dilihat dari ketersediaan infrastruktur yang digunakan untuk mengakomodir kebutuhan Implementasi Pendaftaran Tanah Sistematis Lengkap saat ini dan untuk kedepannya.

Penyediaan sarana dan prasarana kantor menjadi perhatian yang sangat serius, baik penyediaanya maupun efisiensi dalam pemanfaatanya. Dengan adanya Implementasi Kebijakan Pendaftaran Tanah Sistematis Lengkap maka volume pelayanan pertanahan di Kantor Pertanahan Kabupaten Muaro Jambi menjadi tinggi, sehingga untuk menunjang kelancaran dalam pelayanan kepada masyarakat perlu didukung sarana dan prasarana yang memadai diantaranya gedung arsip dan alat ukur. Kantor Pertanahan Kabupaten Muaro Jambi memiliki 2 Seksi yang sudah memiliki gedung arsip dari 6 Seksi yang ada pada Kantor Pertanahan Kabupaten Muaro Jambi.

Selain itu Standar Operasional Prosedur (SOP) Implementasi Kebijakan Pendaftaran Tanah Sistematis Lengkap di Kantor Pertanahan Kabupaten Muaro Jambi sesuai dengan Peraturan Menteri Agraria dan Tata Ruang/Kepala Kantor Pertanahan Kabupaten Muaro Jambi Republik Indonesia Nomor 6 Tahun 2018 tentang Pendaftaran Tanah 
Sistematis Lengkap. Berikut prosedur/ mekanisme pengurusanan Pendaftaran Tanah Sistematis Lengkap di Kabupaten Muaro Jambi.

Kemudian apabila dilihat dari karakteristik para partisipan pada penyelenggaraan PTSL, masih ditemukan karakteristik para partisipan yang yang belum memahami tentang Pendaftaran Tanah Sistematis Lengkap, sebagaimana hasil wawancara dengan Bapak Joko Suanto (warga Desa Gambut Jaya) pada tanggal 12 Maret 2020 di Balai Desa Gambut Jaya Kecamatan Sungai Gelam Kabupaten Muaro Jambi, mengatakan bahwa "saya khawatir kalau nanti tanah saya di sertipikatkan maka pajak tanah saya akan naik”.

Berjalannya Implementasi Kebijakan Pendftatran Tanah Sistematis Lengkap ini dipengaruhi oleh organisasi dalam hal ini petugas penyuluhan untuk menyampaikan kepada masyarakat yang masuk dalam desa lokasi PTSL agar mengikuti Kebijakan Pendftatran Tanah Sistematis Lengkap, sehingga Implementasi Kebijakan Pendftatran Tanah Sistematis Lengkap ini dapat terlaksana dengan baik untuk mewujudkan pemberian kepastian hukum dan perlindungan hukum Hak atas Tanah masyarakat

\section{Karakteristik Organisasi Pelaksana}

Karakteristik utama dari organisasi pelaksana kebijakan dalam hal ini adalah struktur birokrasi dan prosedur-prosedur standar kerja/ Standar Operasional Prosedur (SOP). Berdasarkan hasil wawancara dengan Kepala Kantor Pertanahan Kabupaten Muaro Jambi Bapak Suharna, SH pada tanggal 09 Maret 2020 di Ruang Kerja Kepala Kantor Pertanahan Kabupaten Muaro Jambi, menyatakan bahwa:

"tentunya dalam penyelenggaraan pelayanan, apa yang diinginkan masyarakat harus sesuai dengan yang diberikan. Semua dilakukan sesuai dengan SOP yang berlaku dan ketepatan waktu penyelesaian PTSL"

\section{Komunikasi Antar Organisasi dan Pelaksanaan Kegiatan \\ Pencapaian keberhasilan Implementasi} Kebijakan Pendftatran Tanah Sistematis Lengkap di Kabupaten Muaro Jambi diperlukan komunikasi antara Kantor Pertanahan Kabupaten Muaro Jambi dengan perangkat daerah di Kabupaten Muaro Jambi khususnya Bagian Pertanahan dan Batas Wilayah SETDA Kabupaten Muaro Jambi agar tercapainya target yang optimal.
Berdasarkan hasil wawancara dengan Kepala Bagian Pertanahan dan Batas Wilayah Setda Kabupaten Muaro Jambi Bapak Muhammad Iqbal, SSTP., M.E tanggal 10 Maret di Rumah Dinas Bupati Muaro Jambi, menyatakan bahwa:

"Bentuk komunikasi antar organisasi adalah adanya tim teknis yang terdiri dari gabungan perangkat daerah lingkup Pemerintah Kabupaten Muaro Jambi sebagai penyelenggara Implementasi Kebijakan Pendftatran Tanah Sistematis Lengkap di Kabupaten Muaro Jambi yang dikoordinir oleh Kantor Pertanahan Kabupaten Muaro Jambi, kemudian rutin diadakan rapat terbatas tim teknis dan rapat koordinas untuk mencapai target yang optimal."

Implementasi Kebijakan Pendftatran Tanah Sistematis Lengkap dibentuk tim teknis dengan susunan anggota dari berbagai perangkat daerah lain dan tim teknis serta adanya komunikasi dalam konteks penelitian ini digunakan agar Implementasi Kebijakan Pendaftaran Tanah Sistematis Lengkap (PTSL) di Kabupaten Muaro Jambi dapat berjalan dengan baik.

Dimensi komunikasi dalam Implementasi Kebijakan Pendaftaran Tanah Sistematis Lengkap (PTSL) di Kabupaten Muaro Jambi sangat ditentukan dari beberapa unsur yang terdapat dalam komunikasi yaitu seperti penyampai pesan, isi pesan, media yang digunakan, sasaran penerima pesan, serta perubahan sebagai akibat komunikasi.

Menurut bapak Hasanuddin selaku Kepala Desa Sungai Gelam, pada wawancara tanggal 16 Maret 2020 menyatakan bahwa :

"Program yang dulu PRONA menjadi PTSL masyarakat kami sedikit bingung, apa saja perbedaannya dan bagaimana prosedur dalam mendaftarkan tanah kami untuk disertifikasikan".

Kebijakan Pendaftaran Tanah Sistematis Lengkap (PTSL) belum memenuhi indikator komunikasi seperti transmisi. Hal ini dapat terjadi dikarenakan menurut hasil wawancara peneliti masih menemukan warga dan yang belum paham benar mengenai program Pendaftaran Tanah Sistematis Lengkap (PTSL) serta bagaimana prosedur dan tata cara dalam mendaftarkan. Masyarakat mengharapkan agar lebih sering dalam mensosialisasikan Program tersebut agar nantinya dapat berjalan dengan lancar. 


\section{Sikap Pelaksana}

Implementasi Kebijakan Pendaftaran Tanah Sistematis Lengkap (PTSL) harus berkomitmen dapat berjalan dengan baik. Implementasi Kebijakan Pendaftaran Tanah Sistematis Lengkap (PTSL) ini disambut baik oleh seluruh jajaran pada Pemerintah Kabupaten Muaro Jambi dan Kantor Pertanahan Kabupaten Muaro Jambi.

Sikap dari pelaksana kebijakan adalah faktor yang penting dalam pendekatan pelaksanaan kebijakan publik. Jika pelaksanaan suatu kebijakan ingin efektif, maka para pelaksana kebijakan tidak hanya harus mengetahui apa yang akan dilakukan tetapi juga harus memiliki kemampuan untuk melaksanakannya.

Kecenderungan perilaku atau karakteristik dari pelaksana kebijakan berperan penting untuk mewujudkan implementasi kebijakan yang sesuai dengan tujuan atau sasaran. Karakter penting yang harus dimiliki oleh pelaksana kebijakan misalnya aspek kepatuhan dan bagaimana kebijakan itu diteruskan. Dalam disposisi kebijakan dibedakan menjadi dua yaitu pengetahuan dan pemahaman pelaksana program dan sikap dalam melaksanakan program kebijakan.

a. Pengetahuan dan pemahaman pelaksana terhadap Implementasi Kebijakan Pendaftaran Tanah Sistematis Lengkap (PTSL) di Kabupaten Muaro Jambi.

Faktor pertama ini dapat dikatakan sangat penting sebab dalam hal ini pelaksanaan program akan dilihat dari keberasilan pelaksana memahami dan mengetahui tentang program serta SOP yang berlaku. Dalam Implementasi Kebijakan Pendaftaran Tanah Sistematis Lengkap (PTSL) di Kabupaten Muaro Jambi implementator belum terlalu memahami tugas dan mengetahui apa yang harus dilakukan. Menurut hasil wawancara peneliti dengan Bapak Ismail salah satu masyarakat di Desa Sungai Gelam Kecamatan Sungai Gelam pada wawancara tanggal 16 Maret 2020 menuturkan "Terkadang pengumpulan dari implementator ke Kantor Pertanahan Nasional atau pengumpulan berkas terkesan lama dan membutuhkan biaya”. Hal ini menjelaskan bagaimana pemahaman dan pengetahuan implementator paham mengenai tugas dan apa yang seharusnya di siapkan serta kurangnya komunikasi dengan warga mengakibatkan patok batas membuat lama proses pengukuran tanah itu sendiri. b. Sikap pelaksana terhadap Implementasi Kebijakan Pendaftaran Tanah Sistematis Lengkap (PTSL) di Kabupaten Muaro Jambi

Sikap pelaksana dalam pelaksanaan kebijakan menjadi faktor penting karenanya implementator dituntut untuk bersikap professional dalam bertugas, jika dalam pelaksanaan sikap dari implementator tidak baik, bukan tidak mungkin pelaksanaan kebijakan akan sulit untuk berhasil dan tidak mendapat hasil yang maksimal. Dalam proses pengukuran hingga proses pengimputan Nomor Induk Berkas (NIB) masih sering terjadi salah ketik dan salah nomor sehingga ketika sertipikat yang sudah jadi lalu dibagikan ke masyarakat dikembalikan untuk diperbaiki lagi.

Fakta di atas menjelaskan bahwa sikap dari implementator di Kabupaten Muaro Jambi sudah bisa dikatakan baik meskipun masih terdapat kekeliruan dan keterlambatan dalam menyetorkan data atau berkas yang sudah ada di Desa.

Berdasarkan hal di atas, peneliti menyimpulkan jika implementor bersikap baik terhadap suatu kebijakan tertentu, maka dalam hal ini berarti adanya dukungan, kemungkinan besar mereka melaksanakan kebijakan sebagaimana yang diinginkan oleh pembuat kebijakan.

\section{Lingkungan Sosial, Kultur dan Politik}

Kebijakan Pendaftaran Tanah Sistematis Lengkap (PTSL) merupakan program dari Reforma agraria yang semestinya dilakukan secara riil tidak hanya pada tataran regulasi semata. Melalui Perpres Nomor 86 tahun 2018 pemerintah diharapkan dapat mendestribusikan aset dan memberdayakan petani-petani miskin untuk dapat menggarap lahan milik pemerintah.

Pada dasarnya, sertifikasi hak atas tanah merupakan kewajiban pemerintah sebagaimana diatur dalam berbagai perturan perundangundangan mengenai pertanahan. Narasi reforma agraria sejatinya melampui kedua kebijakan tersebut, yaitu guna memperbaiki ketimpangan yang terjadi. Kebijakan Pendaftaran Tanah Sistematis Lengkap (PTSL) yang dibuat pemerintah berpotensi meningkatkan monopoli hak atas tanah oleh perusahaan swasta. Bukan tidak mungkin, bilamana para petani membutuhkan biaya, pilihan alternatifnya adalah mengagunkan sertipikat hak atas tanah tersebut kepada pihak perbankan, jika tidak 
mampu membayar maka para petani terjebak oleh utang dan timbul siklus kemiskinan baru.

Wawancara yang dilakukan peneliti dengan Bapak Saman Desa Muaro Kumpeh Kecamatan Kumpeh Ulu pada wawancara tanggal 17 Maret 2020, menyatakan :

"saya akan menggunakan sertipikat ini untuk menambah modal usaha saya dengan cara mengagunkan sertipikat ini ke bank".

Hal ini menjelaskan Program Pendaftaran Tanah Sistem Lengkap (PTSL) yang digencarkan oleh Badan Pertanahan Nasional (BPN) akan mampu mendorong pergerakan dan kemajuan ekonomi masyarakat bawah. Sebab, sertipikat yang dimiliki oleh masyarakat bisa menjadi barang berharga yang bisa mereka agunkan kepada pihak bank dan lembaga keuangan. Koordinasi aktif dan komunikasi dengan semua pihak terkait sangat diperlukan dalam mendukung percepatan pelaksanaan PTSL di lapangan, baik dengan aparat pemerintah setempat, tokoh masyarakat maupun dengan masyarakat.

Dari informan dan penelitian di lapangan, maka dapat diketahui bahwa lingkungan sosial dan kultur yang ada di Kabupaten Muaro Jambi bahwa masyarakat cukup memahami maksud dan tujuan dari Implementasi Kebijakan Pendaftaran Tanah Sistematis Lengkap (PTSL), serta faktor politik yang sudah cukup baik dengan adanya dukungan dari kepala daerah.

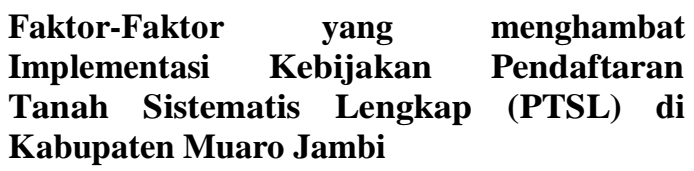

Berdasarkan uraian-uraian di atas peneliti dapat mengidentifikasi beberapa faktor-faktor yang menghambat Implementasi Kebijakan Pendaftaran Tanah Sistematis Lengkap (PTSL) di Kabupaten Muaro Jambi. Pada prinsipnya Implementasi Kebijakan Pendaftaran Tanah Sistematis Lengkap (PTSL) di Kabupaten Muaro Jambi telah berjalan cukup baik, namun dalam pelaksanaannya tidak terlepas dari factorfaktor yang menghambat implementasi.

Peneliti menggunakan model pendekatan implementasi kebijakan yang dirumuskan oleh Van Meter dan Van Horn sebagai berikut:

\section{Standar dan Sasaran Kebijakan}

Kinerja implementasi kebijakan dapat diukur tingkat keberhasilannya dari ukuran dan tujuan kebijakan yang bersifat realistis dengan sosio-kultur yang ada di level pelaksana kebijakan Berdasarkan hasil wawancara yang peneliti dapatkan, standar dan sasaran kebijakan bukan merupakan faktor penghambat Implementasi Kebijakan Kebijakan Pendaftaran Tanah Sistematis Lengkap (PTSL) di Kabupaten Muaro Jambi. Seperti yang disampaikan Warga Desa Muaro Kumpeh Kecamatan Kumpeh Ulu yaitu Bapak Sumarno pada wawancara tanggal 17 Maret 2020, menyatakan bahwa:

"Pelaksanaan kegiatan Pendaftaran Tanah Sistematis Lengkap (PTSL) di Desa kami sudah disosialisasikan dengan jelas. Adapun pihak yang melakukan sosialiasi yaitu dari Kantor Pertanahan Kebuapaten Muaro Jambi dan juga Pihak Pemerintah Kabupaten Muaro Jambi dalam hal ini bagian Pertanahan dan Batas Wilayah. pada setiap sosialisasi antar pihak kantor pertanahan Kabupaten Muaro Jambi maupun pihak Pemerintah Kabupaten Muaro Jambi saling melengkapi dalam memberikan penjelasan dan menjawab pertanyaan dari warga. Dasar saya dapat mengatakan jelas standar dan sasaran kebijakan yaitu saya sebagai warga paham bahwa kegiatan ini adalah program dari Bapak Presiden yang wajib diselesaikan hingga tahun 2025. PTSL ini juga merupakan program pensertipikatan tanah masyarakat pengganti PRONA. Namun PRONA hanya beberapa bidang tanah saja sedang PTSL seluruh bidang tanah”.

Selanjutnya juga ditambahkan Warga Desa Muaro Kumpeh Kecamatan Kumpeh Ulu lainnya yaitu Bapak Effendi pada wawancara tanggal 17 Maret 2020, menyatakan bahwa:

"PTSL ini berbeda dengan PRONA. PRONA tidak untuk semua bidang sedangkan PTSL seluruh bidang tanah yang ada didesa kami harus terukur meskipun belum bisa disertipikatkan. Bahkan fasilitas umum dan fasilitas yang ada didesa kami juga bisa disertipikatkan. Hanya tinggal keinginan kami sebagai masyarakat sendiri mau atau tidak melengkapi dokumen alas hak atas tanah kami sehingga dapat menjadi sertipikat. Kami sangat bersyukur dan berterima kasih sekali PTSL ini dapat dilaksanakan di Desa kami.”

Dari hasil wawancara dengan warga diatas dapat disimpulkan bahwa Standar dan Sararan Kebijakan Pendaftaran Tanah Sistematis Lengkap di Kabupaten Muaro Jambi sudah 
sangat dipahami oleh masyarakat. Ini artinya Standar dan Sararan Kebijakan PTSL di Kabupaten Muaro Jambi sudah bukan merupakan faktor penghambat."

\section{Sumber Daya}

Keberhasilan implementasi kebijakan sangat tergantung dari kemampuan memanfaatkan sumber daya yang tersedia. Manusia merupakan sumber daya yang terpenting dalam menentukan keberhasilan suatu implementasi kebijakan. Setiap tahap implementasi menuntut adanya sumber daya manusia yang berkualitas sesuai dengan pekerjaan yang diisyaratkan oleh kebijakan yang telah ditetapkan secara apolitik. Selain sumber daya manusia, sumber daya finansial dan waktu menjadi perhitungan penting dalam keberhasilan implementasi kebijakan.

Sepeti yang disampaikan Kepala Seksi Penatagunaan Tanah Kantor Pertanahan Kabupaten Muaro Jambi Bapak Ari Wahyudi, S.St pada tanggal 09 Maret 2020, mengatakan bahwa:

"Sarana dan prasarana yang kami gunakan masih kurang. Implementator salah satu tenaga yang sangat penting baik itu dalam hal pengukuran dan pengimputan data, sering kali untuk implementator sendiri tidak menggunakan fasilitas yang cukup serta fasilitasi komunikasi yang kurang sehingga mendapatkan hasil yang kurang maksimal. Pada Implementasi Kebijakan Pendaftaran Tanah Sistematis Lengkap (PTSL) di Kabupaten Muaro Jambi tidak hanya pengukuran saja namun penginputan data sertifikasi harus sesuai dari nama hingga Nomor Induk Berkas (NIB). Dengan jumlah tenaga yang terbatas dan peralatan ukur yang juga terbatas akan berpengaruh terhadap capaian hasil sertipikat yang akan diterbitkan."

Berdasarkan keterangan di atas dapat disimpulkan bahwa Implementasi Kebijakan Pendaftaran Tanah Sistematis Lengkap (PTSL) di Kabupaten Muaro Jambi sudah berjalan namun masih perlu peningkatan lagi dengan menambah tenaga teknis dan fasilitas-fasilitas yang diperlukan sehingga tidak menjadi penghambat dalam penerbitan sertipikat.

\section{Karakteristik Organisasi Pelaksana}

Pusat perhatian pada agen pelaksana meliputi organisasi formal dan organisasi informal yang akan terlibat dalam pengimplementasian kebijakan. Hal ini penting karena kinerja implementasi kebijakan akan sangat dipengaruhi oleh ciri yang tepat serta cocok dengan para agen pelaksananya. Hal ini berkaitan dengan konteks kebijakan yang akan dilaksanakan pada beberapa kebijakan dituntut pelaksana kebijakan yang ketat dan displin. Pada konteks lain diperlukan agen pelaksana yang demokratis dan persuasif. Dari hasil wawancara dengan Kepala Kantor Pertanahan Kabupaten Muaro Jambi Bapak Suharna, SH pada tanggal 09 Maret 2020 mengatakan bahwa:

"Kami melaksanakan kebijakan PTSL ini sesuai dengan Peraturan yang sudah ditetapkan yaitu Peraturan Menteri Agraria dan Tata Ruang/Kepala Kantor Pertanahan Kabupaten Muaro Jambi Republik Indonesia Nomor 6 Tahun 2018 tentang Pendaftaran Tanah Sistematis Lengkap jadi SOP kami sudah jelas".

Dari hasil wawancara diatas dapat disimpulkan bahwa Karakteristik Organisasi Pelaksana Kebijakan Pendaftaran Tanah Sistematis Lengkap di Kabupaten Muaro Jambi sudah saling bersinergi antara Kantor Pertanahan Kabupaten Muaro Jambi dengan Pemerintah Kabupaten Muaro Jambi. Maka artinya Karakteristik Organisasi Pelaksana Kebijakan PTSL di Kabupaten Muaro Jambi bukan merupakan faktor penghambat.

\section{Komunikasi Antar Organisasi dan Pelaksanaan Kegiatan}

Komunikasi dalam kerangka penyampaian informasi kepada para pelaksana kebijakan tentang apa menjadi standar dan tujuan harus konsisten dan seragam (consistency and uniformity) dari berbagai sumber informasi. Dari hasil wawancara dengan kepala Desa Sungai Gelam Bapak Hasanuddin pada tanggal 12 Maret 2020, mengatakan bahwa:

"Dalam pelaksanaan kebijakan PTSL ini kami pihak desa selalu diberikan panduan dan bimbingan dari pihak Pemerintah Kabupaten dan Kantor Pertanahan Kabupaten Muaro Jambi. Mulai dari penyampaian informasi adanya kebijakan PTSL, perencanaan, persiapan, pelaksanaan sampai dengan terbitnya sertipikat. Seandainya ada kami temui permasalahan dalam pelaksanaan pihak pihak Pemerintah Kabupaten dan Kantor Pertanahan Kabupaten Muaro Jambi selalu memberikan saran, masukan bahkan sampai solusi. Dan masyarakat di desa kami pun sudah memahami apa itu PTSL 
dan Bagaimana bisa mendapatkan sertipikat dari kebijakan PTSL ini."

Hal serupa juga disampaikan oleh Kepala Desa Muaro Kumpeh Kecamatan Kumpeh Ulu yaitu Bapak Husin pada wawancara tanggal 17 Maret 2020, menyatakan bahwa:

"Sosialisasi sudah dilakukan dan sudah jelas, kami menerima kebijakan ini karena memang ini baik untuk kemajuan desa agar tanah yang ada di desa dapat terakomodir dengan baik dan mengurangi pencurian tanah. Dari Pemerintah Kabupaten dan Kantor Pertanahan Kabupaten Muaro Jambi selalu membuka ruang kepada kami untuk bertanya dan meminta saran dan masukan apabila kami menemukan permasalah dalam pelaksanaan kebijakan PTSL ini. Bahkan warga kami sangat antusias membuat acara penyerahan sertipikat dan meminta kepada Bupati untuk berkenan memberikan sertipikat secara simbolis dalam acara yang kami buat."

Dari hasil wawancara dengan Kepala Desa diatas dapat disimpulkan bahwa Komunikasi Antar Organisasi dan Pelaksanaan Kegiatan Pendaftaran Tanah Sistematis Lengkap di Kabupaten Muaro Jambi sudah sangat baik dan berhasil. Maka Komunikasi Antar Organisasi dan Pelaksanaan Kegiatan PTSL di Kabupaten Muaro Jambi juga bukan merupakan faktor penghambat.

\section{Sikap Pelaksana}

Kebijakan yang dilaksanakan bukanlah hasil formulasi warga setempat yang mengenal betul permasalahan dan persoalan yang mereka rasakan. Tetapi kebijakan publik biasanya bersifat top down yang sangat mungkin para pengambil keputusan tidak mengetahui bahkan tak mampu menyentuh kebutuhan, keinginan atau permasalahan yang harus diselesaikan”. Menurut hasil wawancara dengan warga Desa Gambut Jaya Bapak Joko Suanto tanggal 12 Maret 2020 yang menyatakan :

Kami sebagai masyarakat sangat berterimakasih dengan adanya kebijakan PTSL karena membantu kami dalam pengamanan tanah atau lahan kebun kami, namun disini masih terdapat kesalahan yang mendasar seperti salah ketik nama, nib dan data yang ada pada sertipikat. Hal ini menyebabkan kami menunggu lama lagi untuk mengganti sertipikat yang terdapat kesalahan.
Pernyataan yang sama juga disampaikan oleh Bapak Syahrul warga Desa Muaro Kumpeh pada wawancara tanggal 17 Maret 2020, yang menyatakan bahwa:

"Saya sendiri yang mengalami menerima sertipikat dengan data sertipikat yang salah data peta bidang tanahnya. Setelah saya menanyakan kepada Kantor Pertanahan Kabupaten Muaro Jambi memang langsung di proses perbaikan namun saya harus menunggu lagi. Saya tanya alasan kenapa bisa terjadi seperti ini, jawabannya Kantor Pertanahan Kabupaten Muaro Jambi dapat melaksanakan kerjanya dengan waktu 10 bulan yang maksimal proses itu selama 12 bulan atau 1 tahun dan untuk waktu pengentrian data hanya dituntut agar dalam waktu 1 (satu) bulan dengan tenaga pengentri yang terbatas."

Dari hasil wawancara diatas dapat disimpulkan bahwa Sikap Pelaksana Kebijakan Pendaftaran Tanah Sistematis Lengkap di Kabupaten Muaro Jambi masih terjadi kesalahan-kesalahan sehingga membuat sertipikat yang sudah jadi harus diperbaiki kembali. Maka Sikap Pelaksana Kebijakan PTSL di Kabupaten Muaro Jambi merupakan faktor penghambat yang diakibatkan oleh batas waktu yang ditentukan tidak sebanding dengan kekuatan personil dan fasilitas.

\section{Lingkungan Sosial, Kultur dan Politik}

Hal terakhir yang perlu diperhatikan guna menilai kinerja implementasi kebijakan adalah sejauh mana lingkungan eksternal turut mendorong keberhasilan kebijakan publik. Lingkungan sosial, ekonomi dan politik yang tidak kondusif dapat menjadi sumber masalah. Karena itu, upaya implementasi kebijakan mensyaratkan kondisi lingkungan eksternal yang kondusif. Seperti yang disampaikan oleh Bapak warga Ibrahim Desa Muaro Kumpeh pada wawancara tanggal 18 Maret 2020, yang menyatakan bahwa:

"Saya tidak ikut membuat sertipikat pada kebijakan PTSL ini karena saya khawatir kata orang-orang untuk mengurus sertipikat itu mahal, lama, dan berbelitbelit. Biaya mahal karena harus membayar akta, PPh, dan BPHTB, prosesnya lama disebabkan butuh waktu harus mengurus akta, membayar pajak, dan proses administrasi di BPN. Adapun kebijakan itu hanya untuk topeng berpolitik dalam mendapatkan perhatian saja dan ujung-ujang juga tetap dipersulit 
dan harus membayar pajak. Karena saya ini orang yang kurang mampu jangankan untuk membayar pajak, untuk makan saja saya sulit”.

Lain halnya dengan penjelasan Bapak Darman warga Desa Gambut Jaya pada wawancara tanggal 17 Maret 2020, yang menyatakan bahwa:

"Tanah saya tidak dapat ikut sertakan pada kebijakan Sertipikat PTSL ini dikarenakan tanah saya ini merupakan lahan cadangan transmigrasi yang merupakan ditentukan dari program transmigrasi pada beberapa tahun yang lalu. Apabila ingin dimasukkan dalam kebijakan PTSL ini maka seluruh warga yang mengalami hal yang sama dengan saya harus disahkan terlebih dahulu dengan Surat Keputusan Bupati tentang Transmigrasi Pengganti dan hal ini perlu kajian yang serius oleh Bupati agar tidak salah dalam memutuskan dan menjadi bahan serangan dari lawan politik bupati. Namun Alhamdulillah Bupati sudah mengeluarkan Surat Keputusan Bupati tentang Transmigrasi Pengganti dan akhirnya lahan kami juga bisa di sertipikatkan."

Terakait penjelasan Bapak Dedi, Kepala Bagian Pertanahan dan Batas Wilayah SETDA Kabupaten Muaro Jambi Bapak Muhammad Iqbal, SSTP., M.E pada tanggal 20 Maret 2020, menyatakan bahwa:

"Memang benar banyak Kepala Desa yang minta agar Batas Desanya diselesaikan guna mengimplementasikan kebijakan PTSL ini. Namun pada setiap kesempatan Sosialisasi PTSL selalu saya sampaikan bahwa batas wilayah tidak akan menghilangkan hak atas tanah. Artinya apabila lebih dahulu tanah mendapatakan alas hak kemudian dengan ditetapkan batas desa menjadi berpindah wilayah maka seluruh administrasi akan di mutasikan dan kami dari pihak kabupaten akan siap membantu. Akan tetapi masih banyak yang berpandangan batas desa ditentukan dengan alas hak tanah seseorang. Maka sekarang ini setiap desa yang mendapatkan kebijakan PTSL saya wajib memprioritaskan untuk menyelesaikan batas desanya."

Dari hasil wawancara diatas dapat disimpulkan bahwa Lingkungan Sosial, Kultur dan Politik Kebijakan Pendaftaran Tanah Sistematis Lengkap di Kabupaten Muaro Jambi masih banyak permasalahan yang harus diselesaikan. Mulai dari pajak, status lahan hinggga batas wilayah yang perlu di sikapi. Maka Lingkungan Sosial, Kultur dan Politik Kebijakan PTSL di Kabupaten Muaro Jambi juga merupakan faktor penghambat.

\section{Strategi Implementasi Kebijakan Pendaftaran Tanah Sistematis Lengkap (PTSL) dan Isu-Isu Strategis di Kabupaten Muaro Jambi}

Teknik yang digunakan peneliti dalam menganalisis dan menyusun strategi adalah dengan menggunakan teknis analisis SWOT. Analisis SWOT digunakan sebagai alat untuk menganalisis permasalahan yang terdapat dalam rumusan masalah yang berhubungan dengan faktor-faktor yang mempengaruhi yaitu faktor internal dan faktor eksternal dalam menyusun strategi yang digunakan untuk keberhasilan Implementasi Kebijakan Pendaftaran Tanah Sistematis Lengkap (PTSL) di Kabupaten Muaro Jambi, yang kemudian peneliti tentukan isu-isu strategis menggunakan litmus test Matriks analisis SWOT dapat dilihat pada tabel berikut ini: 
Tabel 4.1

Matriks SWOT

Implementasi Kebijakan Pendaftaran Tanah Sistematis Lengkap (PTSL) di Kabupaten Muaro Jambi

\begin{tabular}{|c|c|c|}
\hline Faktor Eksternal & $\begin{array}{l}\text { Kekuatan (Strengths) } \\
\text { 1. Sudah adanya Peraturan Bupati } \\
\text { tentang Kelembagaan } \\
\text { Pemerintah Daerah Kabupaten } \\
\text { Muaro Jambi yang menangani } \\
\text { tugas pokok dan fungsi bidang } \\
\text { pertanahan; } \\
\text { 2. Adanya Peraturan Bupati } \\
\text { Nomor } 7 \text { Tahun } 2019 \text { tentang } \\
\text { Pembiayaan Persiapan } \\
\text { Pendaftaran Tanah Sistematis } \\
\text { Lengkap yang dibebankan } \\
\text { kepada Masyarakat di } \\
\text { Kabupaten Muaro Jambi; } \\
\text { 3. Adanya Keputusan Bupati } \\
\text { Muaro Jambi Nomor } \\
\text { 214/Kep.Bup/BPN/2020 } \\
\text { tentang Pemebentukan Tim } \\
\text { Gugus Tugas Reforma Agraria } \\
\text { di Kabupaten Muaro Jambi; } \\
\text { Adanya dukungan anggaran } \\
\text { dari Pemerintah Kabupaten } \\
\text { Muaro Jambi meskipun hanya } \\
\text { dalam bentuk kegiatan fasilitasi } \\
\text { dan sosialisasi pendaftaran } \\
\text { tanah pada Bagian Pertanahan } \\
\text { dan Batas Wilayah SETDA } \\
\text { Kabupaten Muaro Jambi. }\end{array}$ & $\begin{array}{l}\text { Kelemahan (Weakness) } \\
\text { 1. Sosialisasi Implementasi } \\
\text { Kebijakan Pendaftaran Tanah } \\
\text { Sistematis Lengkap (PTSL) di } \\
\text { Kabupaten Muaro Jambi belum } \\
\text { menyeluruh, baru terbatas } \\
\text { kepada masyarakat desa yang di } \\
\text { tentukan lokasinya sebagai desa } \\
\text { yang mendapatkan PTSL; } \\
\text { 2. Anggaran dari Pemerintah } \\
\text { Kabupaten yang masih minim } \\
\text { yaitu hanya untuk sosialisasi di } \\
\text { beberapa saja; } \\
\text { 3. Ketersediaan sarana dan } \\
\text { prasarana masih kurang; } \\
\text { 4. Jarak tempuh Desa ke } \\
\text { Kabupaten yang jauh serta } \\
\text { Akses transportasi (infrastruktur } \\
\text { jalan) yang masih sulit di } \\
\text { tempuh; Kepala Desa yang } \\
\text { 5. Integritas Kas } \\
\text { masih berorientasi dengan uang. }\end{array}$ \\
\hline $\begin{array}{l}\text { Peluang (Opportunities) } \\
\text { 1. Adanya Keputusan Bersama } \\
\text { Menteri Menteri Agraria dan } \\
\text { Tata Ruang/Kepala Kantor } \\
\text { Pertanahan Kabupaten } \\
\text { Muaro Jambi Republik } \\
\text { Indonesia, Menteri dalam } \\
\text { Negeri Republik Indonesia, } \\
\text { Menteri Desa, Pembangunan } \\
\text { Daerah Tertinggal dan } \\
\text { Transmigrasi } \\
\text { Nomor:25/SKB/V/2017, } \\
\text { Nomor:590-3167A Tahun } \\
\text { 2017 dan Nomor:34 Tahun } \\
\text { 2017 tentang Pembiayan } \\
\text { Persiapan Pendaftaran Tanah } \\
\text { Sistematis; } \\
\text { 2. Adanya pembagian pekerjaan } \\
\text { Implementasi Kebijakan } \\
\text { Pendaftaran Tanah } \\
\text { Sistematis Lengkap (PTSL) } \\
\text { dengan Pihak ketiga; } \\
\text { 3. Kabupaten Muaro Jambi } \\
\text { yang merupakan daerah } \\
\text { penyangga (hinterland) dari }\end{array}$ & $\begin{array}{l}\text { Strategi SO } \\
\text { 1. Meningkatkan } \\
\text { pemerintah daerah } r \text { dalam } \\
\text { Implementasi } \\
\text { Pendaftaran Tanah Sistematis } \\
\text { Lengkap (PTSL). } \\
\text { 2. Mengoptimalkan fungsi daerah } \\
\text { penyangga (hinterland) dari Kota } \\
\text { Jambi serta Mengoptimalkan } \\
\text { fungsi Masyarakat Kabupaten } \\
\text { Muaro Jambi yang heterogen } \\
\text { dalam Implementasi Kebijakan } \\
\text { Pendaftaran Tanah Sistematis } \\
\text { Lengkap (PTSL). }\end{array}$ & 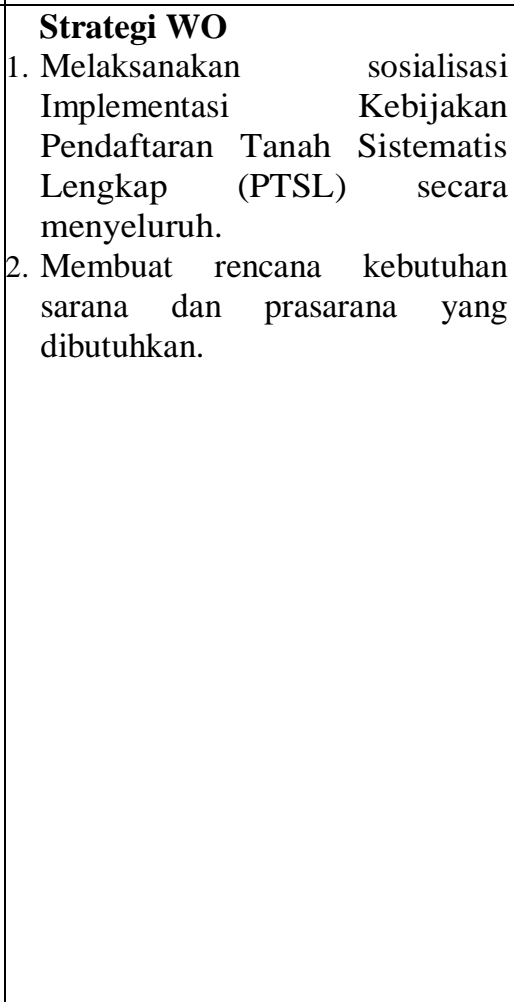 \\
\hline
\end{tabular}




\begin{tabular}{|c|c|c|}
\hline $\begin{array}{l}\text { Kota Jambi. } \\
\text { 4. Masyarakat } \\
\begin{array}{l}\text { Muaro Kabupaten } \\
\text { heterogen. }\end{array}\end{array}$ & & \\
\hline $\begin{array}{l}\text { Ancaman (Threats) } \\
\text { 1. Belum selesainya Peraturan } \\
\text { Menteri Dalam Negeri } \\
\text { tentang Batas Wilayah } \\
\text { Kabupaten Muaro Jambi } \\
\text { dengan Kabupaten } \\
\text { Batanghari dan Kabupaten } \\
\text { Tanjung Jabung Timur; } \\
\text { 2. Masalah batas desa yang } \\
\text { masih banyak belum } \\
\text { terselesaikan; } \\
\text { 3. Banyaknya } \\
\text { pertanahan yang diakibatkan } \\
\text { terbitnya Hak Guna Usaha } \\
\text { yang belum selesai proses } \\
\text { peralihan lahannya (Jual beli, } \\
\text { ganti rugi, kompensasi dan } \\
\text { lain sebagainya); } \\
\text { 4. Adanya masyarakat yang } \\
\text { mengelola lahan kawasan } \\
\text { hutan; } \\
\text { 5. Gangguan jaringan internet } \\
\text { dan jaringan listrik yang } \\
\text { tidak stabil. }\end{array}$ & $\begin{array}{l}\text { Strategi ST } \\
\text { 1. Mengoptimalkan fungsi Bagian } \\
\text { Pertanahan dan Batas Wilayah } \\
\text { dalam menyelesaikan } \\
\text { Masalah Pertanahan dan Batas } \\
\text { Wilayah. } \\
\text { 2. Bekerja sama dengan PLN dan } \\
\text { pihak penyedia jaringan internet } \\
\text { untuk memperbaiki kualitas } \\
\text { jaringan. }\end{array}$ & $\begin{array}{l}\text { Strategi WT } \\
\text { 1. Melaksanakan forum komunikasi } \\
\text { dan koordinasi dengan perangkat } \\
\text { daerah terkait sehingga } \\
\text { Implementasi } \\
\text { Pendaftaran Tanah Sistematis } \\
\begin{array}{l}\text { Lengkap (PTSL) dapat berjalan } \\
\text { baik. }\end{array}\end{array}$ \\
\hline
\end{tabular}

Sumber: Diolah Peneliti, 2021

Tabel 4.2

Isu Strategis yang Ditetapkan Berdasarkan Kategori Kestrategisannya

\begin{tabular}{|c|l|c|c|}
\hline No & \multicolumn{1}{|c|}{ Isu Strategis } & Skor & Kriteria Isu \\
\hline 1 & $\begin{array}{l}\text { Meningkatkan komitmen pemerintah daerah dalam Implementasi } \\
\text { Kebijakan Pendaftaran Tanah Sistematis Lengkap (PTSL). }\end{array}$ & 34 & Sangat Strategis \\
\hline 2 & $\begin{array}{l}\text { Mengoptimalkan fungsi daerah penyangga (hinterland) dari Kota } \\
\text { Jambi serta Mengoptimalkan fungsi Masyarakat dalam Implementasi } \\
\text { Kebijakan Pendaftaran Tanah Sistematis Lengkap (PTSL). }\end{array}$ & 20 & $\begin{array}{c}\text { Bersifat } \\
\text { Operasional }\end{array}$ \\
\hline 3 & $\begin{array}{l}\text { Melaksanakan sosialisasi Implementasi Kebijakan Pendaftaran } \\
\text { Tanah Sistematis Lengkap (PTSL) secara menyeluruh. }\end{array}$ & 33 & Sangat Strategis \\
\hline 4 & Membuat rencana kebutuhan sarana dan prasarana yang dibutuhkan. & 30 & Cukup Strategis \\
\hline 5 & $\begin{array}{l}\text { Mengoptimalkan fungsi Bagian Pertanahan dan Batas Wilayah dalam } \\
\text { menyelesaikan Masalah Pertanahan dan Batas Wilayah. }\end{array}$ & 36 & Sangat Strategis \\
\hline 6 & $\begin{array}{l}\text { Bekerja sama dengan PLN dan pihak penyedia jaringan internet } \\
\text { untuk memperbaiki kualitas jaringan. }\end{array}$ & 22 & Cukup Strategis \\
\hline 7 & $\begin{array}{l}\text { Melaksanakan forum komunikasi dan koordinasi dengan perangkat } \\
\text { daerah terkait sehingga Implementasi Kebijakan Pendaftaran Tanah } \\
\text { Sistematis Lengkap (PTSL) dapat berjalan baik }\end{array}$ & 27 & Cukup Strategis \\
\hline
\end{tabular}

Sumber: Diolah Peneliti, 2021 


\section{KESIMPULAN}

Kesimpulan

Berdasarkan hasil penelitian dan pembahasan, maka dapat peneliti simpulkan sebagai berikut:

1. Implementasi Kebijakan Pendaftaran Tanah Sistematis Lengkap (PTSL) di Kabupaten Muaro Jambi belum berjalan optimal. Meihat aspek lingkungan sosial dan kultur yang cukup memahami Kebijakan Pendaftaran Tanah Sistematis Lengkap (PTSL), serta faktor politik yang sudah cukup baik dengan adanya dukungan dari kepala daerah. Namun dilihat dari aspek standar dan sasaran kebijakan serta aspek sumber daya berupa sarana prasarana/ fasilitas penunjang walaupun belum mencapai target yang sempurna, dan dari menunjukkan masih, sedangkan sumber daya manusia yang memiliki kompetensi dan keahlian dalam Implementasi Pendaftaran Tanah Sistematis Lengkap masih kurang.

2. Faktor-faktor yang menghambat Implementasi Kebijakan Pendaftaran Tanah Sistematis Lengkap (PTSL) di Kabupaten Muaro Jambi yaitu Sumber Daya, Sikap Pelakssana serta Lingkungan Sosial, Kultur dan Politik.

3. Strategi yang sebaiknya dilakukan untuk keberhasilan Implementasi Kebijakan Pendaftaran Tanah Sistematis Lengkap (PTSL) di Kabupaten Muaro Jambi adalah:

a. Mengoptimalkan fungsi Bagian Pertanahan dan Batas Wilayah dalam menyelesaikan Masalah Pertanahan dan Batas Wilayah.

b. Meningkatkan komitmen pemerintah daerah dalam Implementasi Kebijakan Pendaftaran Tanah Sistematis Lengkap (PTSL).

c. Melaksanakan sosialisasi Implementasi Kebijakan Pendaftaran Tanah Sistematis Lengkap (PTSL) secara menyeluruh.

\section{Saran}

\section{Saran Praktis}

1. Terhadap faktor Sumber Daya yang merupakan penghambat maka Kantor Pertanahan Kabupaten Muaro Jambi diharapkan bekerja sama yang baik dengan Pemerintah Kabupaten Muaro Jambi sehingga dapat lebih fokus kepada ketersediaan sumber daya pada Implementasi Kebijakan Pendaftaran Tanah Sistematis Lengkap (PTSL) di Kabupaten Muaro Jambi yaitu sumber daya finansial, sumber daya infrastruktur teknologi informasi, sumber daya manusia yang kompeten.

2. Terhadap faktor Sikap Pelaksana yang merupakan penghambat maka Kantor Pertanahan Kabupaten Muaro Jambi diharapkan selalu mengevaluasi hasil kerja anggotanya serta perlu dilakukannya pemberian reward dan punishment kepada pegawai sebagai motivasi dalam bekerja

3. Terhadap faktor Lingkungan Sosial, Kultur dan Politik yang merupakan penghambat maka Kantor Pertanahan Kabupaten Muaro Jambi bersama dengan Pemerintah Kabupaten Muaro Jambi sebaiknya dapat melakukan studi banding dengan Kantor Pertanahan lain yang telah/lebih sukses menerapkan Implementasi Kebijakan Pendaftaran Tanah Sistematis Lengkap (PTSL), agar dapat menjadi pembelajaran demi meningkatkan hasil Implementasi Kebijakan Pendaftaran Tanah Sistematis Lengkap (PTSL) yang lebih optimal.

\section{Saran Teoritis}

1. Untuk peneliti selanjutnya yang menggunakan objek penelitian yang sama, diharapkan dapat menggunakan desain penelitian dan teknik analisis data yang berbeda agar lebih memperbanyak sumber-sumber dan referensi yang akurat terkait permasalahan yang diangkat.

2. Diharapkan juga bagi yang hendak melakukan penelitian yang sama agar dapat melakukan kajian dari permasalahan dan sudut pandang yang berbeda atau menggunakan variabel penelitian yang berbeda, sehingga nantinya akan memperluas khasanah pengetahuan bagi peneliti dan pembaca. 


\section{DAFTAR PUSTAKA}

Agustino, Leo. 2008. Dasar-Dasar Kebijakan Publik. Bandung: Alfabeta.

Akadun. 2009. Tekhnologi Informasi Administrasi. Bandung: Alfabeta.

Ali, Lukman. 2007. Kamus Istilah Sastra. Jakarta: Balai Pustaka.

Arikunto, Suharsimi. 2010. Prosedur Penelitian. Jakarta: Rineka Cipta.

Badudu, J.S dan Sutan Muhammad Zain. 2010. Kamus Umum Bahasa Indonesia. Jakarta: Integrafika.

Bryson, John M. 2008. Perencanaan Strategis bagi Organisasi Sosial. Yogyakarta: Pustaka Pelajar.

Bungin, Burhan. 2009. Penelitian Kualitatif. Jakarta: Kencana.

Creswell, John W. 2014. Perencanaan Design (Pendekatan Kualitatif, Kuantitatif, dan Mixed). Yogyakarta: Pustaka Pelajar.

Deddy, Mulyana. 2013. Metodologi Penelitian Kualitatif. Bandung: Remaja Rosdakarya.

Dunn, William. 2003. Pengantar Analisis Kebijakan Publik. Yogyakarta: Gadjah Mada University Press.

Effendy, Khasan. 2010. Memadukan Metode Kuantitatif dan Kualitatif. Bandung: CV. Indra Prahasta.

Gulo, W. 2010. Metodologi Penelitian. Jakarta: Grasindo.

Hamidi. 2004. Metode Penelitian Kualitatif Pendekatan Praktis Penulisan Proposal dan Laporan Penelitian. Malang: UMM Press.

Hasibuan, Malayu S.P. 2001. Manajemen Dasar, Pengertian dan Masalah. Jakarta: Bumi Aksara.

Hunger, J David. 2003. Manajemen Strategis. Yogyakarta: Andi.

Indrajit, Richardus Eko dkk. 2005. EGovernment In Action Ragam Kasus Implementasi Sukses di Berbagai Belahan Dunia. Yogyakarta: Andi.

\begin{tabular}{c} 
Strategi \\
\hline Pembangunan
\end{tabular} Pengembangan Sistem Pelayanan Publik Berbasis Teknologi Digital. Yogyakarta: Andi.

Inu Kencana Syafiie, Pengantar ilmu pemerintahan, Jakarta, Refika Aditama, 2010

Irawan, Prasetya. 2007. Penelitian Kualitatif dan Kuantitatif untuk Ilmu-ilmu Sosial. Jakarta: DIA FISIP UI.
Koswara, E. 2002. Otonomi Daerah untuk Daerah dan Kemandirian Rakyat. Jakarta: Candi Cipta Piramida. 2003. Pokok-Pokok Kuliah Teori Pemerintahan Daerah. Jakarta: Program Pasca Sarjana MIP.

Marrus, Stephanie K. 2002. Desain Penelitian Manajemen Strategik. Jakarta: Rajawali Press.

Moekijat. 2005. Pengembangan Organisasi. Bandung: Mandar Maju.

Moenir. 2006. Manajemen Pelayanan Umum di Indonesia. Jakarta: Bumi Aksara.

Nazir, Moh. 2014. Metode Penelitian. Bogor: Ghalia Indonesia.

Ni'matull Huda. 2012. Hukum Pemerintah Daerah, Nusamedia:Bandung.

Nugroho, Riant. 2003. Kebijakan Publik: Formulasi, Implementasi dan Evaluasi. Jakarta: Alex Media Komputindo.

Peraturan Menteri Agraria dan Tata Ruang/Kepala Badan Pertanahan Nasional (BPN) Republik Indonesia Nomor 35 Tahun 2016 Tentang Percepatan Pelaksanaan Pendaftaran Tanah Sistematis Lengkap.

Peraturan Menteri Agraria dan Tata Ruang/Kepala Badan Pertanahan Nasional (BPN) Republik Indonesia Nomor 12 Tahun 2017 Tentang Percepatan Pendaftaran Tanah Sistematis Lengkap

Rangkuti, Freddy. 2014. Analaisis SWOT Teknik Membedah Kasus Bisnis. Jakarta: Gramedia Pustaka Utama.

Ratminto dan Atik Winarsih. 2012. Manajemen Pelayanan. Yogyakarta: Pustaka Pelajar.

Ridwan. 2004. Metode dan Teknik Menyusun Tesis. Bandung: Alfabeta.

Sedarmayanti. 2009. Manajemen Sumber Daya Manusia. Bandung: Refika Aditama.

Siagian, Sondang P. 2008. Manajemen Sumber Daya Manusia. Jakarta: Bumi Aksara.

Silalahi, Ulber. 2010. Metodologi Penelitian Sosial. Bandung: Refika Aditama.

Simangunsong, Fernandes. 2016. Metodologi Penelitian Pemerintahan. Bandung: Alfabeta.

Sinambela, Lijan Poltak. 2010. Reformasi Pelayanan Publik. Jakarta: Bumi Aksara.

Sugiyono. 2007. Metode Penelitian Pendidikan Pendekatan Kuantitatif, Kualitatif, dan $R \& D$. Bandung: Alfabeta.

2010. Metode Penelitian Kuantitatif, Kualitatif dan R\&D. Bandung: Alfabeta.

2013. Metode Penelitian Bisnis. Bandung: Alfabeta. 
Sumanto, 2014. Teori dan Aplikasi Metode Penelitian. Yogyakarta: Centre of Acamdemic Publishing Service (CAPS).

Sumaryadi, I Nyoman. 2010. Sosiologi Pemerintahan: Dari Perspektif Pelayanan, Pemberdayaan, Interaksi, dan Sistem Kepemimpinan Pemerintahan Indonesia. Bogor: Ghalia Indonesia. Pemerintahan, Menuju Tata Kelola Pemerintahan yang Baik. Bogor: Ghalia Indonesia.

Surat Keputusan Bersama 3 Menteri: Menteri Agraria dan Tata Ruang/Kepala Badan Pertanahan Nasional (BPN), Menteri Dalam Negeri, Menteri Desa, Pembangunan Daerah Tertinggal Dan Transmigrasi Tentang Pembiayaan Persiapan Pendaftaran Tanah Sistematis Lengkap.

Sutarman. 2012. Pengantar Teknologi Informasi. Jakarta: Bumi Aksara.

Suyanto, M. 2005. Multimedia Alat Untuk Meningkatkan Keunggulan Bersaing. Yogyakarta: Andi Yogyakarta.
Syafri, Wirman dan Setyoko, P. Israwan. 2008. Implementasi Kebijakan Publik dan Etika Profesi Pamong Praja. Sumedang: Alqaprint Jatinangor.

Tjokroamidjojo, Bintoro dan Mustopadidjaya. 1998. Teori dan Strategi Pembangunan Nasional. Jakarta: Haji Mas Agung.

Undang-Undang Nomor 5 Tahun 1960 Tentang Peraturan Dasar Pokok-Pokok Agraria (UUPA).

Van Meter, Donald S and Carl E. Van Horn. 1975. The Policy Implementation Process: A Conceptual Framework. Ohio: Department of Political Science Ohio State University.

Wahab, Solichin Abdul. 2012. Analisis Kebijakan: Dari Formulasi ke Implementasi Kebijakan Negara. Jakarta: Bumi Aksara.

Wicaksono. 2006. Administrasi dan Birokrasi Pemerintah. Yogyakarta: Graha Ilmu.

Zuriah, Nurul. 2009. Metodologi Penelitian Sosial dan Pendidikan. Jakarta: Bumi Aksara. 